\title{
Effect of Opposite Clear Corneal Incision (CCI) on Corneal Higher-Order Aberrations after Phacoemulsification
}

\author{
HANY M. EL IBIARY, M.D.; RAFAAT A. REHAAN, M.D.; TAREK M. ABD AL-AZIZ, M.D. and \\ HATEM A.A. GAMAL ELDIN, M.Sc.
}

The Department of Ophthalmology, Faculty of Medicine, Ain Shams University

\begin{abstract}
Background: Nowadays, care of a cataractous patient greatly exceeds surgical removal of the opacified lens. In a step foreword to welfare of the elderly, phacoemulsification can perform as a refractive tool, addressing both spherical and astigmatic refractive errors.

Aim of Study: The aim of that work was to evaluate safety and effectiveness of OCCIs, as an innovative procedure for correction of corneal astigmatism, during phacoemulsification.

Patients and Methods: The study assessed 64 patients, who underwent phacoemulsification. Pre-operative and postoperative corneal topography was done, documented and statistically analyzed for each patient.

Results: The study revealed a decrease of pre-operative corneal astigmatism from a pre-operative mean of $-1.78 \mathrm{D}$ to a post-operative mean of 1.09D in OCCI group and a decrease of pre-operative corneal astigmatism from a pre-operative mean of $-1.71 \mathrm{D}$ to a postoperative mean of 1.29D in single incision group.

Conclusion: The present study revealed that OCCIs with appropriate pre-operative corneal topography represent a real advance in the applications of refractive lenticular surgery. OCCIs provide an innovative technique for managing preoperative, regular, corneal astigmatism. This is simple, easy to learn technique, with no extra instrumentation. The OCCIs in this study was safe, with no wound related complications. However, OCCIs require careful early post-operative care, due to their penetrating nature. Once the wounds are sealed, risk of further complications approaches zero. Further studies on that technique, employing different incision architecture are required to help development of nomograms correlating the incision length, width, age of the patient, and the amount of pre-operative corneal astigmatism to be corrected.
\end{abstract}

Key Words: Opposite clear corneal incision - Corneal higherorder aberrations - Phacoemulsification.

\section{Introduction}

MODERN cataract surgery is a refractive procedure whereby one basically can achieve the targeted

Correspondence to: Dr. Hatem A.A. Gamal Eldin, E-Mail: hatemayman35@yahoo.com post-operative refraction. To achieve this goal, biometry, mathematical calculation of IOL power and astigmatism management are important factors $[1,2]$.

Patients undergoing cataract surgery expect clear vision and less dependence on spectacles. To attain this goal, one important consideration is reduction of astigmatism. Modern cataract surgery using small incisions and foldable IOLs has led to achieving emmetropia in a great number of patients [3].

Modifications in surgical technique and incisions may further improve refractive outcomes by reduction of astigmatism [4].

Although astigmatism can be corrected after cataract surgery, it is more appropriate to combine both procedures [5].

Preexisting corneal astigmatism at the time of cataract surgery can be treated by manipulation of cataract incision, limbal relaxing incision, astigmatic keratotomy, or implantation of toric intraocular lenses [6,7]

Astigmatic keratotomy entails drawbacks such as glare sensation, diplopia and fluctuation of refractive error due to proximity of the incisions to the center cornea. In addition, it requires preoperative pachymetry and use of a diamond knife [8].

Limbal relaxing incisions are another method for correction of preexisting corneal astigmatism; advantages include being technically easy, producing less symptoms, earlier wound stabilization due to the location of the incision and inducing no change in spherical equivalent when 2 incisions are made due to coupling effect. However, this method also suffers from limitations such as re- 
quiring pachymetry and use of a diamond knife

Implantation of toric IOLs is another option, however these lenses are expensive and their implantation requires additional skills; moreover, post-operative rotation remains a major drawback

Excimer laser ablation may also be used to correct residual or induced astigmatism after cataract surgery. Major concerns include the cost of the procedure, limited number of centers equipped with excimer machines, adverse effects specific to excimer laser surgery such as loss of BCVA, flap related complications, night vision disturbances and regression [11]

Recruiting the incision construction during cataract surgery, making it on the steep corneal axis is the simplest method for astigmatism correction. This may be difficult or impossible with certain axes. The amount of correction using this method varies but is usually reported to be less than 1D [12].

The individual choice of incision (on axis surgery: Incision in the steeper meridian, length, shape and location concerning cornea or sclera) reduces the pre-operatively existing astigmatism [13]

It is well documented that the $3.0 \mathrm{~mm}$ temporal clear corneal incision induces between 0.28 and 0.53 diopters of temporal flattening, with no effect on the nasal corneal curvature. A longer clear corneal incision induces a greater flattening effect [14].

Construction of Opposite Clear Corneal Incisions (OCCIs) is a relatively simple technique requiring neither extra instrumentation nor extra expertise. The technique is relatively easy to learn because it is used in the standard phacoemulsification incision on the steep axis plus another extra corneal incision opposite the original incision [15]

OCCIs have been tried by many in phacoemulsification cataract surgery and have been found to have better neutralizing effect on astigmatism than single clear corneal incision [15].

Since HOAs can impact visual performance and contrast sensitivity, they are considered important indices in the field of quality of vision and deserve attention. In addition, today, attention to HOAs after laser refractive surgery has become one of the important issues in the assessment of the quality of laser refractive methods. Implantation of intraocular lenses has caused many studies to demonstrate changes in HOAs after surgery. There has been more attention to HOAs among cataract patients and myopes compared to other ocular conditions. The decision to correct HOAs or not is a challenging one for which no definite answer has been found [16].

\section{Aim of the study:}

The aim of that work was to evaluate safety and effectiveness of OCCIs, as an innovative procedure for correction of corneal astigmatism, during phacoemulsification.

\section{Patients and Methods}

Our study included 64 eyes of 64 patients with cataract. They were gathered from Ophthalmology Outpatient Clinic - Ain Shams University Hospital in the period from November 2019 till April 2020. All cases were candidates for cataract surgery by phacoemulsification.

The nature of the procedures was explained to the participants in detail and a written informed consent was given by all participants. The study was consistent with the principles of Helsinki declaration.

Inclusion criteria: Included any patient undergoing phacoemulsification surgery with topographic astigmatism of more than 1.00 diopter.

Exclusion criteria were: Any previous ocular surgery, corneal lesions, scars, degenerations or dystrophies, glaucomas and irregular astigmatism.

Pre-operative assessment: All patients were subjected to complete history taking, including the general medical condition and the ocular morbidity, with emphasis on history of ocular trauma and surgeries. Complete Ophthalmic examination was carried out, including uncorrected and best corrected visual acuities, slit lamp biomicroscopy, IOP measurement and fundus examination.

All patients underwent corneal topography to determine the diopteric power of the cornea in the principal meridians and calculate the preoperative corneal astigmatism. The CSO Sirus pentacam with Scheimpflug technology was used for all cases of the study. The instrument determined the corneal surface aberrations calculated from the Placido disk capture, and Zernike coefficient values were obtained. With the patient's cooperation and a stable tear film, HOAs were measured several times and a clear reading was selected for use in the study. In this study, since the correlation between eyes was low in terms of Root Mean Square (RMS) of HOAs $\left(r^{1} / 40.277\right)$. 
Each Zernike term was reported as a corresponding Zernike coefficient with its sign. Approximately 1 week after surgery, corneal HOAs were measured using the Zernike coefficient values and compared with the preoperative data. To evaluate the changes in corneal aberrations, the RMS of the HOAs for total, coma, trifoil, spherical aberrations, astigmatism, and HOA with were studied one week pre-operatively and one week post-operatively at follow-up visit.

Keratometry was performed using NIDEK KM500 keratometer for obtaining $\mathrm{K} 1$ and $\mathrm{K} 2$ values. $\mathrm{A}$ and $\mathrm{B}$ scanning was then performed for calculation of the IOL power to be implanted. The SRK II formula was employed in cases with axial length $<24 \mathrm{~mm}$ and the SRK-T formula in cases with axial length $>24 \mathrm{~mm}$.

Corneal topographic imaging: Each patient was comfortably seated and positioned with his chin resting on the chin rest and his forehead supported against the forehead rest, the chin rest was adjusted, so that the patient's lateral canthus align with the black mark on the forehead rest shaft, the patient's eye was observed through the LCD monitor and brought into focus using the joystick, a perfectly focused topography of the cornea was taken and printed out for documentation and further analysis.

Pre-operative preparation: 24 hours before surgery, each patient was prescribed moxifloxacin eye drops, to be instilled five times/day, two hours before surgery mydriasis was achieved by topical instillation of Tropicamide HCL 1\%, Phenylephrine $2.5 \%$; every 30 minutes; with concurrent topical instillation of Diclophenac sodium $0.1 \%$.

Anesthesia: Cases were operated under local retrobulbar anesthesia. A 1:1 mixture of Mepivacaine HCL2\% and Bupivacaine 0.5\% was used for local infiltration.

Surgical procedure: Sterilization of the periocular skin with Povidone Iodine $10 \%$ and the conjunctival sac with Povidone Iodine 5\%. Followed by flushing of the conjunctival sac by saline, application of wire speculum.

At the edge of the vascular arcade, one step CCI was done, using a $2.6 \mathrm{~mm}$ keratome. This was affected by passing the keratome for $2 \mathrm{~mm}$ through the corneal stroma; in a plane parallel to the iris; then penetrating the Descemet's membrane and entering the anterior chamber. That was a width of the incision was $2.6 \mathrm{~mm}$ Fig. (1).

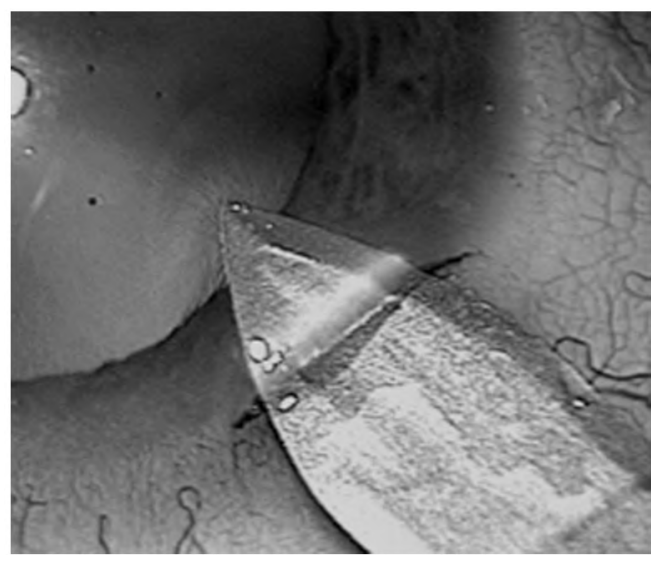

Fig. (1): One-step clear corneal incision.

Sodium Hyaluronate was injected to fill the anterior chamber, two limbal side ports were done, using an MVR, continuous, circular, curvilinear capsulorhexis was done; employing trypan blue $0.1 \%$ for capsule staining, whenever needed, hydrodissection, then hydrodelineation; whenever needed. emulsification of the nucleus was carried out, employing the divide and conquer technique; employing the phacoemulsification machine, irrigation/Aspiration of the remaining cortical matter, sodium Hyaluronate was injected to inflate the capsular bag. A $12.5 \mathrm{~mm}$ long; $6.0 \mathrm{~mm}$ optic, hydrophilic acrylic IOL was implanted into the capsular bag, the OCCI was then made 180 degrees away from the first incision on the same detected meridian.

It is noteworthy that, the steepest meridian was marked immediately pre-operatively on the slitlamp.

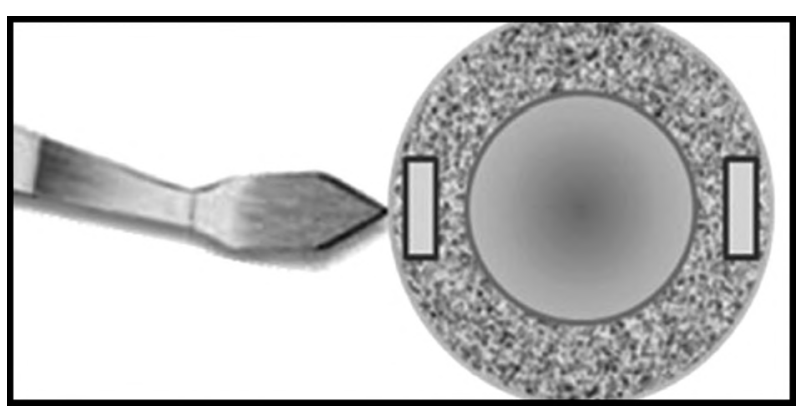

Fig. (2): Site of the OCCIs.

In cases with with-the-rule astigmatism, the corneal tunnel was made at the superior cornea, while the OCCI was made at the inferior cornea.

In cases with against-the-rule astigmatism, the corneal tunnel was made temporally, while the OCCI was made nasally.

In cases with oblique astigmatism, the OCCIs were made 180 degrees apart on the steepest meridian. 


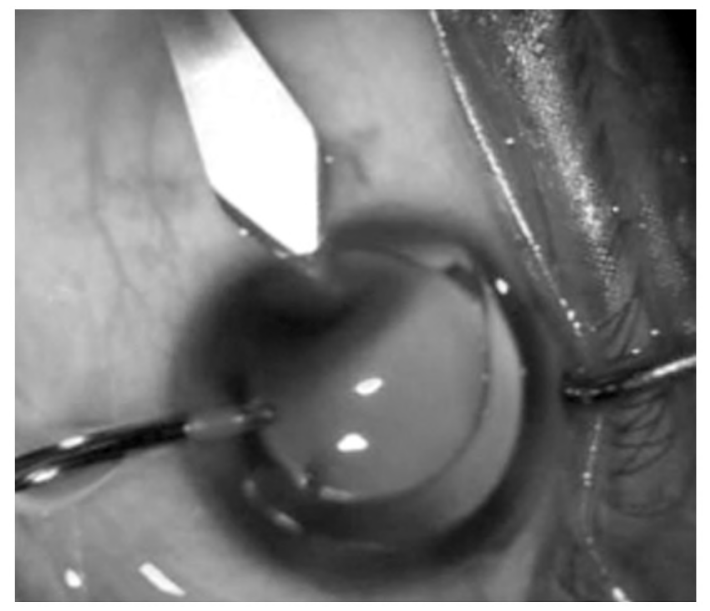

Fig. (3): OCCIs.

Aspiration of the remaining viscoelastic was then carried out, Wound closure was ensured by stromal hydration of the edges of the corneal tunnel and side port incisions, sterile eye pad was applied, the operative events were documented.

Post-operative follow-up: All patients received topical steroid-antibiotic drops; 4 times/day; for the first two weeks post-operatively. Frequency of application was gradually tapered over a month.

All patients were examined in the first postoperative day, then had follow-up visits planned after one week post-operatively. At each visit, each patient was subject to:

UCVA, slit lamp biomicroscopy to examine the corneal clarity and tightness of the incisions, fundus examination, refraction and BCVA, iOP measurement, corneal topography was scheduled at one week post-operative visit.

\section{Results}

Patients enrolled into that study, 64 patients (64 eyes) who matched our inclusion criteria, underwent phacoemulsification and PC-IOL implantation for cataract, combined with OCCI for correction of pre-operative astigmatism in the second group.

Table (1): Demographic data of the studied sample.

\begin{tabular}{lll}
\hline & $\begin{array}{c}\text { OCCI group } \\
\text { No.=32 }\end{array}$ & $\begin{array}{c}\text { Single incision group } \\
\text { No.=32 }\end{array}$ \\
\hline $\begin{array}{l}\text { Age: } \\
\text { Mean } \pm \text { SD }\end{array}$ & $62.72 \pm 7.83$ & $62.31 \pm 7.31$ \\
Range & $45-75$ & $45-73$ \\
Sex: & & \\
$\quad$ Females & $17(53.1 \%)$ & $14(43.8 \%)$ \\
Males & $15(46.9 \%)$ & $18(56.2 \%)$ \\
Side: & & $12(37.5 \%)$ \\
OD & $13(40.6 \%)$ & $20(62.5 \%)$ \\
OS & $19(59.4 \%)$ & \\
\hline
\end{tabular}

Table (2): Comparison between pre and post in OCCI group.

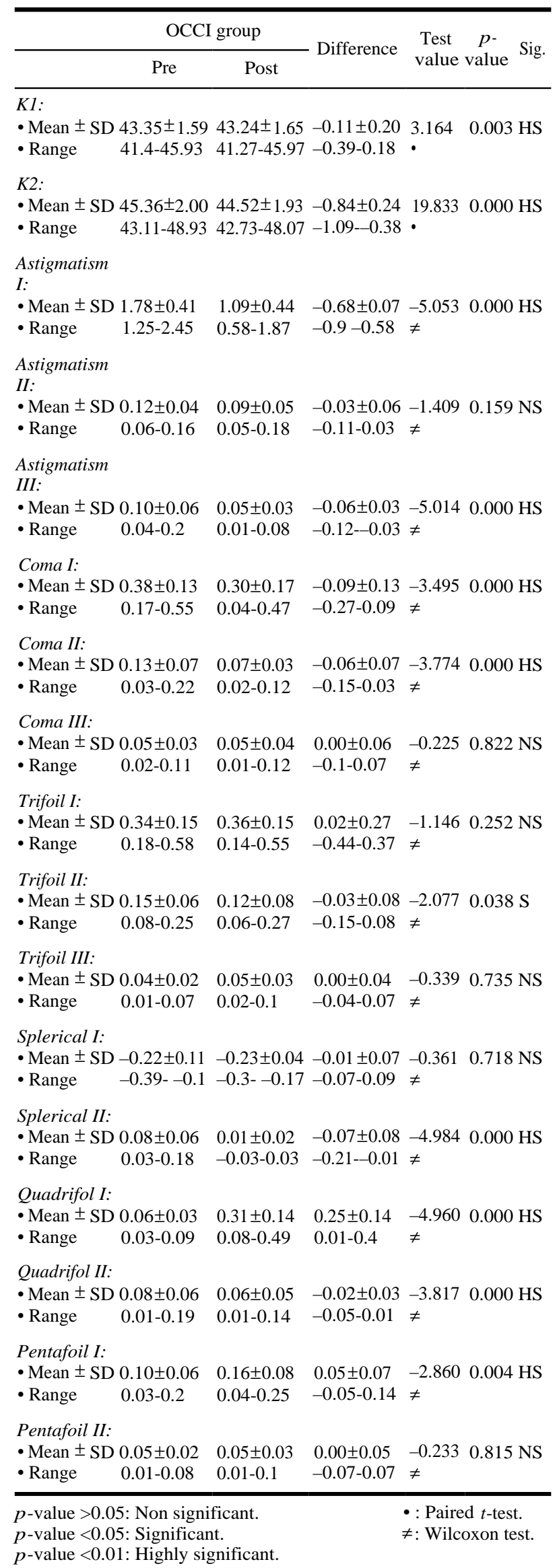


Table (3): Comparison between pre and post in single incision group.

\begin{tabular}{|c|c|c|c|c|}
\hline \multicolumn{2}{|c|}{ Single incision group } & \multirow{2}{*}{ - Difference } & \multirow{2}{*}{\multicolumn{2}{|c|}{$\begin{array}{c}\text { Test } \\
\text { value value }\end{array}$ Sig }} \\
\hline Pre & Post & & & \\
\hline $\begin{array}{l}\text { K1: } \\
\text { - Mean } \pm \text { SD } 42.16 \pm 1.14 \\
\text { - Range } \quad 40.11-43.7\end{array}$ & $\begin{array}{l}42.20 \pm 1.18 \\
39.98-43.7\end{array}$ & $\begin{array}{l}42.20 \pm 1.18 \\
39.98-43.7\end{array}$ & $\begin{array}{l}-0.883 \\
\cdot\end{array}$ & $0.384 \mathrm{NS}$ \\
\hline $\begin{array}{l}K 2: \\
- \text { Mean } \pm \text { SD } 44.13 \pm 1.26 \\
\text { - Range } \quad 41.64-46.14\end{array}$ & $\begin{array}{l}43.71 \pm 1.20 \\
41.32-45.69\end{array}$ & $\begin{array}{l}43.71 \pm 1.20 \\
41.32-45.69\end{array}$ & 2.950 & $0.006 \mathrm{HS}$ \\
\hline 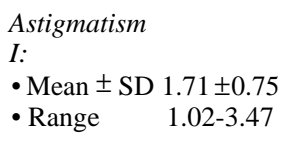 & $\begin{array}{l}1.29 \pm 0.68 \\
0.71-2.92\end{array}$ & $\begin{array}{l}1.29 \pm 0.68 \\
0.71-2.92\end{array}$ & $\begin{array}{l}-4.832 \\
\neq\end{array}$ & $0.000 \mathrm{HS}$ \\
\hline 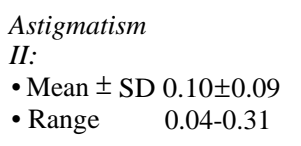 & $\begin{array}{l}0.09 \pm 0.09 \\
0.01-0.34\end{array}$ & $\begin{array}{l}0.09 \pm 0.09 \\
0.01-0.34\end{array}$ & $\begin{array}{l}-0.590 \\
\neq\end{array}$ & $0.555 \mathrm{NS}$ \\
\hline 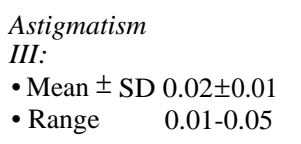 & $\begin{array}{l}0.02 \pm 0.01 \\
0-0.04\end{array}$ & $\begin{array}{l}0.02 \pm 0.01 \\
0-0.04\end{array}$ & $\begin{array}{l}-2.738 \\
\neq\end{array}$ & $0.006 \mathrm{HS}$ \\
\hline 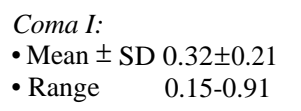 & $\begin{array}{l}0.23 \pm 0.09 \\
0.1-0.39\end{array}$ & $\begin{array}{l}0.23 \pm 0.09 \\
0.1-0.39\end{array}$ & $\begin{array}{l}-1.463 \\
\neq\end{array}$ & $0.143 \mathrm{NS}$ \\
\hline $\begin{array}{l}\text { Coma II: } \\
\text { - Mean } \pm \text { SD } 0.05 \pm 0.04 \\
\text { - Range } \quad 0.01-0.16\end{array}$ & $\begin{array}{l}0.04 \pm 0.02 \\
0.01-0.08\end{array}$ & $\begin{array}{l}0.04 \pm 0.02 \\
0.01-0.08\end{array}$ & $\begin{array}{l}-1.637 \\
\neq\end{array}$ & $0.102 \mathrm{NS}$ \\
\hline $\begin{array}{l}\text { Coma III: } \\
\text { - Mean } \pm \text { SD } 0.03 \pm 0.02 \\
\text { - Range } \quad 0-0.06\end{array}$ & $\begin{array}{l}0.01 \pm 0.01 \\
0-0.02\end{array}$ & $\begin{array}{l}0.01 \pm 0.01 \\
0-0.02\end{array}$ & $\begin{array}{l}-3.300 \\
\neq\end{array}$ & $0.001 \mathrm{HS}$ \\
\hline $\begin{array}{l}\text { Trifoil I: } \\
\text { - Mean } \pm \text { SD } 0.19 \pm 0.11 \\
\text { - Range } \quad 0.05-0.45\end{array}$ & $\begin{array}{l}0.18 \pm 0.13 \\
0.08-0.55\end{array}$ & $\begin{array}{l}0.18 \pm 0.13 \\
0.08-0.55\end{array}$ & $\begin{array}{l}-0.815 \\
\neq\end{array}$ & $0.415 \mathrm{NS}$ \\
\hline $\begin{array}{l}\text { Trifoil II: } \\
\text { - Mean } \pm \text { SD } 0.06 \pm 0.07 \\
\text { - Range } \quad 0-0.26\end{array}$ & $\begin{array}{l}0.04 \pm 0.02 \\
0.01-0.09\end{array}$ & $\begin{array}{l}0.04 \pm 0.02 \\
0.01-0.09\end{array}$ & $\begin{array}{l}-2.147 \\
\neq\end{array}$ & $0.032 \mathrm{~S}$ \\
\hline $\begin{array}{l}\text { Trifoil III: } \\
\begin{array}{ll}\text { - Mean } \pm \text { SD } & 0.02 \pm 0.02 \\
\text { - Range } \quad 0-0.06\end{array}\end{array}$ & $\begin{array}{l}0.03 \pm 0.04 \\
0-0.13\end{array}$ & $\begin{array}{l}0.03 \pm 0.04 \\
0-0.13\end{array}$ & $\begin{array}{l}-0.425 \\
\neq\end{array}$ & $0.671 \mathrm{NS}$ \\
\hline $\begin{array}{l}\text { Splerical I: } \\
- \text { Mean } \pm \text { SD }-0.20 \pm 0.09 \\
\text { - Range } \quad-0.36-0.09\end{array}$ & $\begin{array}{l}-0.21 \pm 0.09 \\
-0.36-0.08\end{array}$ & $\begin{array}{l}-0.21 \pm 0.09 \\
-0.36-0.08\end{array}$ & $\begin{array}{l}-0.076 \\
\neq\end{array}$ & $0.939 \mathrm{NS}$ \\
\hline $\begin{array}{l}\text { Splerical II: } \\
\text { - Mean } \pm \text { SD } 0.01 \pm 0.04 \\
\text { - Range } \quad-0.05-0.07\end{array}$ & $\begin{array}{l}0.02 \pm 0.01 \\
0-0.04\end{array}$ & $\begin{array}{l}0.02 \pm 0.01 \\
0-0.04\end{array}$ & $\begin{array}{l}-0.736 \\
\neq\end{array}$ & $0.461 \mathrm{NS}$ \\
\hline $\begin{array}{l}\text { Quadrifol I: } \\
\text { - Mean } \pm \text { SD } 0.08 \pm 0.03 \\
\text { - Range } \quad 0.04-0.13\end{array}$ & $\begin{array}{l}0.12 \pm 0.13 \\
0.03-0.49\end{array}$ & $\begin{array}{l}0.12 \pm 0.13 \\
0.03-0.49\end{array}$ & $\begin{array}{l}-0.253 \\
\neq\end{array}$ & $0.800 \mathrm{NS}$ \\
\hline $\begin{array}{l}\text { Quadrifol II: } \\
\text { - Mean } \pm \text { SD } \\
\text { - Range } \quad 0.21 \pm 0.59\end{array}$ & $\begin{array}{l}0.30 \pm 0.88 \\
0-3\end{array}$ & $\begin{array}{l}0.30 \pm 0.88 \\
0-3\end{array}$ & $\begin{array}{l}-0.327 \\
\neq\end{array}$ & $0.744 \mathrm{NS}$ \\
\hline $\begin{array}{l}\text { Pentafoil I: } \\
\text { - Mean } \pm \text { SD } 0.05 \pm 0.02 \\
\text { - Range } \quad 0.01-0.11\end{array}$ & $\begin{array}{l}0.06 \pm 0.07 \\
0.01-0.25\end{array}$ & $\begin{array}{l}0.06 \pm 0.07 \\
0.01-0.25\end{array}$ & $\begin{array}{l}-2.065 \\
\neq\end{array}$ & $0.039 \mathrm{~S}$ \\
\hline $\begin{array}{l}\text { Pentafoil II: } \\
\text { - Mean } \pm \text { SD } 0.02 \pm 0.02 \\
\text { - Range } \quad 0-0.06\end{array}$ & $\begin{array}{l}0.03 \pm 0.01 \\
0.01-0.05\end{array}$ & $\begin{array}{l}0.03 \pm 0.01 \\
0.01-0.05\end{array}$ & $\begin{array}{l}-0.952 \\
\neq\end{array}$ & $0.341 \mathrm{NS}$ \\
\hline $\begin{array}{l}\text {-value }>0.05: \text { Non sig } \\
\text {-value }<0.05: \text { Signific }\end{array}$ & ant. & & $\begin{array}{l}\bullet: \text { Paire } \\
\neq: \text { Wilc }\end{array}$ & $\begin{array}{l}\text { ed } t \text {-test. } \\
\text { coxon test. }\end{array}$ \\
\hline
\end{tabular}

Table (4): Comparison between the difference in both groups.

\begin{tabular}{|c|c|c|c|c|c|}
\hline Difference & $\begin{array}{l}\text { OCCI group } \\
\text { No.=32 }\end{array}$ & $\begin{array}{l}\text { Single incision } \\
\text { group } \\
\text { No.=32 }\end{array}$ & $\begin{array}{c}\text { Test } \\
\text { value }\end{array}$ & $\begin{array}{c}p- \\
\text { value }\end{array}$ & Sig. \\
\hline $\begin{array}{l}\text { K1: } \\
\cdot \text { Mean } \pm \mathrm{SD} \\
\cdot \text { Range }\end{array}$ & $\begin{array}{l}-0.11 \pm 0.20 \\
-0.39-0.18\end{array}$ & $\begin{array}{l}0.04 \pm 0.27 \\
-0.58-0.44\end{array}$ & $-2.864 \neq$ & 0.004 & HS \\
\hline $\begin{array}{l}K 2: \\
\cdot \text { Mean } \pm \mathrm{SD} \\
\cdot \text { Range }\end{array}$ & $\begin{array}{l}-0.84 \pm 0.24 \\
-1.09--0.38\end{array}$ & $\begin{array}{l}-0.42 \pm 0.81 \\
-2.38-1.28\end{array}$ & $-4.472 \neq$ & 0.000 & HS \\
\hline $\begin{array}{l}\text { Astigmatism } \\
\text { I: } \\
\text { - Mean } \pm \text { SD } \\
\text { - Range }\end{array}$ & $\begin{array}{l}-0.68 \pm 0.07 \\
-0.9--0.58\end{array}$ & $\begin{array}{l}-0.42 \pm 0.25 \\
-0.82-0.18\end{array}$ & $-4.944 \neq$ & 0.000 & HS \\
\hline $\begin{array}{l}\text { Astigmatism } \\
\text { II: } \\
\text { - Mean } \pm \text { SD } \\
\text { - Range }\end{array}$ & $\begin{array}{l}-0.03 \pm 0.06 \\
-0.11-0.03\end{array}$ & $\begin{array}{l}-0.01 \pm 0.09 \\
-0.24-0.07\end{array}$ & $-1.933 \neq$ & 0.053 & NS \\
\hline $\begin{array}{l}\text { Astigmatism } \\
\text { III: } \\
\text { - Mean } \pm \text { SD } \\
\text { - Range }\end{array}$ & $\begin{array}{l}-0.06 \pm 0.03 \\
-0.12--0.03\end{array}$ & $\begin{array}{l}-0.01 \pm 0.02 \\
-0.05-0.01\end{array}$ & $-6.237 \neq$ & 0.000 & HS \\
\hline $\begin{array}{l}\text { Coma I: } \\
\text { - Mean } \pm \text { SD } \\
\text { - Range }\end{array}$ & $\begin{array}{l}-0.09 \pm 0.13 \\
-0.27-0.09\end{array}$ & $\begin{array}{l}-0.09 \pm 0.24 \\
-0.75-0.13\end{array}$ & $-1.443 \neq$ & 0.149 & NS \\
\hline $\begin{array}{l}\text { Coma II: } \\
\text { - Mean } \pm \text { SD } \\
\text { - Range }\end{array}$ & $\begin{array}{l}-0.06 \pm 0.07 \\
-0.15-0.03\end{array}$ & $\begin{array}{l}-0.01 \pm 0.04 \\
-0.08-0.03\end{array}$ & $-2.458 \neq$ & 0.014 & S \\
\hline $\begin{array}{l}\text { Coma III: } \\
\text { - Mean } \pm \text { SD } \\
\text { - Range }\end{array}$ & $\begin{array}{l}0.00 \pm 0.06 \\
-0.1-0.07\end{array}$ & $\begin{array}{l}-0.01 \pm 0.02 \\
-0.04-0.01\end{array}$ & $-1.745 \neq$ & 0.081 & NS \\
\hline $\begin{array}{l}\text { Trifoil I: } \\
\text { - Mean } \pm \text { SD } \\
\text { - Range }\end{array}$ & $\begin{array}{l}0.02 \pm 0.27 \\
-0.44-0.37\end{array}$ & $\begin{array}{l}0.003 \pm 0.16 \\
-0.22-0.37\end{array}$ & $-1.956 \neq$ & 0.050 & NS \\
\hline $\begin{array}{l}\text { Trifoil II: } \\
\text { - Mean } \pm \text { SD } \\
\text { - Range }\end{array}$ & $\begin{array}{l}-0.03 \pm 0.08 \\
-0.15-0.08\end{array}$ & $\begin{array}{l}-0.02 \pm 0.07 \\
-0.22-0.02\end{array}$ & $-1.686 \neq$ & 0.092 & NS \\
\hline $\begin{array}{l}\text { Trifoil III: } \\
\text { - Mean } \pm \text { SD } \\
\text { - Range }\end{array}$ & $\begin{array}{l}0.00 \pm 0.04 \\
-0.04-0.07\end{array}$ & $\begin{array}{l}0.00 \pm 0.04 \\
-0.05-0.11\end{array}$ & $-0.149 \neq$ & 0.881 & NS \\
\hline $\begin{array}{l}\text { Splerical I: } \\
\cdot \text { Mean } \pm \text { SD } \\
\cdot \text { Range }\end{array}$ & $\begin{array}{l}-0.01 \pm 0.07 \\
-0.07-0.09\end{array}$ & $\begin{array}{l}0.00 \pm 0.07 \\
-0.17-0.1\end{array}$ & $-0.651 \neq$ & 0.515 & NS \\
\hline $\begin{array}{l}\text { Splerical II: } \\
\cdot \text { Mean } \pm \text { SD } \\
- \text { Range }\end{array}$ & $\begin{array}{l}-0.07 \pm 0.08 \\
-0.21--0.01\end{array}$ & $\begin{array}{l}0.01 \pm 0.04 \\
-0.04-0.09\end{array}$ & $-4.859 \neq$ & 0.000 & HS \\
\hline $\begin{array}{l}\text { Quadrifol I: } \\
\text { - Mean } \pm \text { SD } \\
\cdot \text { Range }\end{array}$ & $\begin{array}{l}0.25 \pm 0.14 \\
0.01-0.4\end{array}$ & $\begin{array}{l}0.04 \pm 0.13 \\
-0.06-0.4\end{array}$ & $-4.840 \neq$ & 0.000 & HS \\
\hline $\begin{array}{l}\text { Quadrifol II: } \\
\text { - Mean } \pm \text { SD } \\
\text { - Range }\end{array}$ & $\begin{array}{l}-0.02 \pm 0.03 \\
-0.05-0.01\end{array}$ & $\begin{array}{l}0.09 \pm 1.11 \\
-1.97-3\end{array}$ & $-2.122 \neq$ & 0.034 & S \\
\hline $\begin{array}{l}\text { Pentafoil I: } \\
\cdot \text { Mean } \pm \text { SD } \\
\cdot \text { Range }\end{array}$ & $\begin{array}{l}0.05 \pm 0.07 \\
-0.05-0.14\end{array}$ & $\begin{array}{l}0.02 \pm 0.05 \\
-0.05-0.14\end{array}$ & $-1.852 \neq$ & 0.064 & NS \\
\hline $\begin{array}{l}\text { Pentafoil II: } \\
\text { - Mean } \pm \text { SD } \\
\text { - Range }\end{array}$ & $\begin{array}{l}0.00 \pm 0.05 \\
-0.07-0.07\end{array}$ & $\begin{array}{c}0.00 \pm 0.02 \\
-0.03-0.03\end{array}$ & $-0.313 \neq$ & 0.755 & NS \\
\hline
\end{tabular}




\section{Discussion}

In this study, 64 eyes of 64 patients have been operated on, for Cataract. All patients have undergone phacoemulsification surgery. In a step forward towards patients' welfare; corneal topography for each patient was obtained. OCCIs have been planned, in an attempt to decrease the pre-operative astigmatism, which could have compromised the visual outcomes of our patients.

In this study, the steepest axis was marked preoperatively on the slitlamp, using an astigmatic marker, the same was carried out by Qammar and Mullaney [4]; who recommended marking the steep axis before anaesthesia; while the patient is sitting to avoid cyclotorsion effect of the oblique muscles.

In this study, the OCCIs were constructed as a one-step CCI for each incision, using $2.6 \mathrm{~mm}$ disposable keratome. We have affected an incision length of around $2 \mathrm{~mm}$. Lever and Dahan [12] ; used a diamond knife to create a one-step OCCIs 2.8 to $3.2 \mathrm{~mm}$ in width and around $1.5 \mathrm{~mm}$ in length.

OCCIs, involving approximately $50 \%$ of the corneal thickness in each step. Tadros et al. [5] used a one-step OCCIs $2.8 \mathrm{~mm}$ in width and 2 to $2.5 \mathrm{~mm}$ in length.

In our study, the OCCIs were not employed for phacoemulsification, as they were done at the end of the procedure.

Lever and Dahan [12] did the OCCIs at the start of the procedure, however they recommended not to use it for phacoemulsificaqtion.

While Tadros et al. [5]; reported that the OCCIs could be used for hydrodissection, irrigation/ aspiration and even posterior capsular polishing.

OCCIs were never sutured in this study, only hydration was employed for affecting tight closure of the incisions. Cases which required suturing were excluded from that study. The same strategy was employed by Tadros et al. [5].

Lever and Dahan, [12]; in their initial study, did not suture the corneal incisions. However, in 2001 they have recommended suturing of OCCIs in high risk cases, such as incisions wider than $3.2 \mathrm{~mm}$. They have reported that sutures may be removed in a week or two, according to the surgeon's clinical judgment.

In that study, the mean astigmatic correction was 0.68 diopters in the OCCI group and the mean astigmatic correction was 0.42 diopters in the single incision group.
In their initial study by Lever and Dahan, [12] they have reported a mean astigmatic correction of 2 diopters. This difference between both studies may be attributed to the fact that Lever and Dahan [12] used variable incision lengths; ranging from 2.8 to $3.5 \mathrm{~mm}$, according to variability in preoperative astigmatism; from 2 up to 5 diopters. On the other hand, we employed a fixed incision length $(2.6 \mathrm{~mm})$ for all patients, with a pre-operative range of astigmatism between 1.25 to 3.47 diopters.

Khokhar et al. [17]; reported a mean astigmatic correction of 1.6 diopters. Tadros et al. [5]; reported $0.5 \mathrm{D}$ as a mean astigmatic correction using OCCIs technique. Both studies used a standard incision length of $3.5 \mathrm{~mm}$.

Our study showed that the reduction of astigmatism was statistically significant $(p<0.05)$. The same was reported by Lever and Dahan [12].

In the present study, patients with pre-operative corneal astigmatism of less than $2.75 \mathrm{D}$ benefited much from OCCIs, while patients with preoperative corneal astigmatism of more than $2.75 \mathrm{D}$ benefited least.

However, no single patient recorded an increase in his pre-operative astigmatism. A study by Mendicute et al. [18]; reported a single patient to have acquired increase in his pre-operative corneal astigmatism value,along with axis shift. That was attributed to over-flattening, due to poor healing of the cornea in old age. On searching the patient's pre-operative data, his pre-operative topography was found to be suggestive of irregular astigmatism as $\mathrm{KISA}=394$.

In the present study, we recorded no CCI related complications. All wounds were perfectly sealed from the first post-operative day. The same was reported by Lever and Dahan in their original study, in 2000 .

In our study, we noticed slight non-significant changes in higher order aberrations from preoperative to post-operative. The same was reported by Elkady [19] as they found that no statistically significant changes were found in any aberration post-operatively and all aberration values decreased slightly, with no statistically significant differences between the follow-up visits.

\section{Conclusion:}

The present study revealed that OCCIs with appropriate pre-operative corneal topography represent a real advance in the applications of refractive lenticular surgery. 
OCCIs provide an innovative technique for managing pre-operative, regular, corneal astigmatism. This is simple, easy to learn technique, with no extra instrumentation.

The OCCIs in this study was safe, with no wound related complications. However, OCCIs require careful early post-operative care, due to their penetrating nature. Once the wounds are sealed, risk of further complications approaches zero.

Further studies on that technique, employing different incision architecture are required to help development of nomograms correlating the incision length, width, age of the patient, and the amount of pre-operative corneal astigmatism to be corrected.

\section{References}

1- ROSEN E.S.: Opposite clear corneal incisions. J. Cat. Ref. Surg., 26 (6): 789-90, 2000.

2- NICHAMIN L.D.: Expanding the role of bioptics to the pseudophakic patient. J. Cat. Ref. Surg., 27 (9): 1343-4, 2001.

3- AZAR D.T.: Intraocular Lenses in Cataract and Refractive Surgery. Arch. Ophthalmol., 120 (7): 1003, 2002.

4- QAMMAR A., and MULLANEY P.: Paired opposite clear corneal incisions to correct preexisting astigmatism in cataract patients. Journal of Cataract \& Refractive Surgery, 31 (6): 1167-70, 2005.

5- TADROS A., HABIB M., TEJWANI D., VON LANY H. and THOMAS P.: Opposite clear corneal incisions on the steep meridian in phacoemulsification: Early effects on the cornea. J. Cat. Ref. Surg., 30 (2): 414-7, 2004.

6- LINDSTROM R.L. and LINDQUIST T.D.: Surgical correction of post-operative astigmatism. Cornea, 7 (2): 13848, 1987.

7- BUCKHURST P.J., WOLFFSOHN J.S., DAVIES L.N. and NAROO S.A.: Surgical correction of astigmatism during cataract surgery. Clinical and Experimental Optometry, 93 (6): 409-18, 2010.

8- MÜLLER-JENSEN K., FISCHER P. and SIEPE U.: Limbal relaxing incisions to correct astigmatism in clear corneal cataract surgery. J. Refract Surg. (Thorofare, NJ: 1995), 15 (5): 586-9, 1998.

9- NICHAMIN L.D.: Astigmatism control. Ophthalmology Clinics of North America, 19 (4): 485-93, 2006.

10- STOJANOVIC A. and NITTER T.A.: Excimer laser in the treatment of myopic astigmatism; outcomes of laser in situ keratomileusis and photorefractive keratectomy. J. Cat. Ref. Surg., 27: 1263-77, 2001.

11-MATSUMOTO Y., HARA T., CHIBA K. and CHIKUDA M.: Optimal incision sites to obtain an astigmatism-free cornea after cataract surgery with a $3.2 \mathrm{~mm}$ sutureless incision. J. Cat. Ref. Surg., 27 (10): 1615-9, 2001.

12-LEVER J. and DAHAN E.: Opposite clear corneal incisions to correct pre-existing astigmatism in cataract surgery. $\mathrm{J}$ Cat. Ref. Surg., 26 (6): 803-5, 2000.

13- PFLEGER T., SKORPIK C., MENAPACE R., SCHOLZ U., WEGHAUPT H. and ZEHETMAYER M.: Long-term course of induced astigmatism after clear corneal incision cataract surgery. J. Cat. Ref. Surg., 22 (1): 72-7, 1996.

14- HAYASHI K., HAYASHI H., NAKAO F. and HAYASHI F.: The correlation between incision size and corneal shape changes in sutureless cataract surgery. Ophthalmology, 102 (4): 550-6, 1995.

15- BAZZAZI N., BARAZANDEH B., KASHANI M. and RASOULI M.: Opposite clear corneal incisions versus steep meridian incision phacoemulsification for correction of pre-existing astigmatism. Journal of ophthalmic and vision research, 3 (2): 87, 2008

16- LI T., ZHOU X. and CHEN Z.: Relationship between ocular wavefront aberrations and refractive error in Chinese school children. Clin. Exp. Optom., 95: 399-403, 2012

17- KHOKHAR S., LOHIYA P., MURUGIESAN V. and PANDA A.: Corneal astigmatism correction with opposite clear corneal incisions or single clear corneal incision: Comparative analysis. Journal of Cataract \& Refractive Surgery, 32 (9): 1432-7, 2006.

18- MENDICUTE J., IRIGOYEN C., RUIZ M., ILLARRAMENDI I., FERRER-BLASCO T. and MONTÉS-MICÓ R.: Toric intraocular lens versus opposite clear corneal incisions to correct astigmatism in eyes having cataract surgery. J. Cat. Ref. Surg., 35 (3): 451-8, 2009.

19- ELKADY B., ALIÓ J.L., ORTIZ D. and MONTALBÁN R.: Corneal aberrations after microincision cataract surgery. Journal of Cataract \& Refractive Surgery, 34 (1): 40-5. 34 (1): 40-5, 2008 


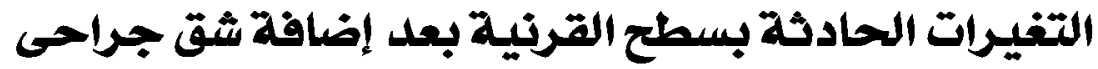

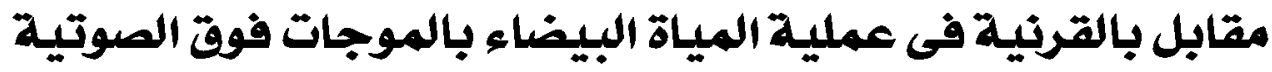

إن الهدف من هذا العمل هو تقييم درجة آمان وفعالية الفتحات الجراحية المتقابلة بالقرنية لتصحيح اللا نقطية المنتظمة فى عمليات تفتيت المياة البيضاء بالموجات فوق الصوتية.

القد إكتسبت عمليات تفتيت عدسة العين البللورية بالموجات فوق الصوتية إنتشاراً فى مجال جراحات المياه البيضاء، خاصة بعد تطات العقد

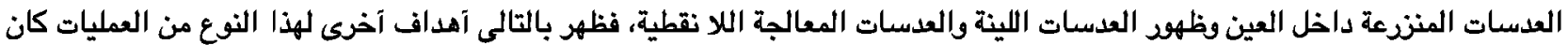
منها ضمان جودة الرؤية عن طريق إصلاح العيوب الإنكسارية للعين.

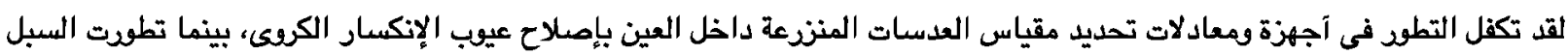

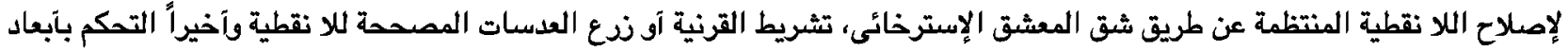
القتحات الجراحية وإستخدام الفتحات الجراحية المتقابلة.

القد بنى البحث على متابعة ع7 مريض من مرضى المياة البيضاء وفحصهم فحصاً كاملاً قبل إجراء عملية المياة البيضاء على آن يتضمن البهاء الفحص تخطيط سطح القرنية وقياس تحدب سطح القرنية ثم متابعة المرضى مجال البحث بعد التدخل الجراحى، على آن يتم مقارنة النتائج والتعبير عنها بإستخدام الوسائل الإحصائية المعبرة.

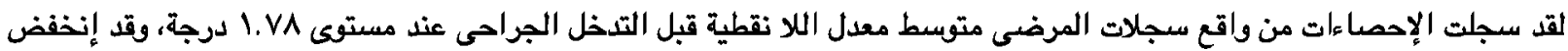
إلى 9 . . 1 درجة بعد التدخل الجراحى بإضافة شنق جراحى مقابل بالقرنية. 